\title{
プロテオグリカン糖鎖を構造特異的に検出する ヘテロバイファンクショナルクロスリンカーの応用
}

プロテオグリカンは，1本または複数のグリコサミノ グリカンと呼ばれる糖鎖がコアタンパク質に共有結合し た，線虫から哺乳類まで広く見られる分子で，生体内で は細胞表面や細胞外マトリクスに分布している(1). プロ テオグリカンに独自の機能をもたらすグリコサミノグリ カンは, アミノ糖誘導体とウロン酸あるいはガラクトー スの二糖を構成単位として，その繰り返し配列が 100 残 基にも及ぶ直鎖状多糖体である。グリコサミノグリカン は, 繰り返し二糖単位の種類により, ヒアルロン酸，コ ンドロイチン硫酸，デルマタン硫酸，ヘパラン硫酸，へ パリン，ケラタン硫酸に分類される。 これらのうち, ヒ アルロン酸以外のものはすべて高度に硫酸化修飾を受け ており, 硫酸基の含量や修飾位置の違いがさまざまな生 物学的機能に対応していることが知られている(2). たと えば，動物細胞に普遍的に存在するへパラン硫酸に見ら れる多様な硫酸化パターンは，複数種の硫酸基転移酵素 による分子内への硫酸基の導入と脱硫酸化酵素の作用に よって形成される。これら酵素群の発現は, 細胞外の環 境の変化に応じて制御され，結果として生み出された特 定の硫酸化パターンを有する糖鎖構造は細胞の機能を変 化させ，ひいては器官や組織における生理作用の調節に 重要な役割を果たしていると考えられている ${ }^{(3)}$.

こうした硫酸化糖鎖による生体機能調節の詳細を明ら かにするためには，特有の硫酸化パターンを有する糖鎖 構造の局在と生理機能との間の相関を検討する必要があ るが，硫酸化糖鎖は抗原性にそしいことから抗体の作製 が困難であり，既存の抗体を利用した免疫染色法による 可視化は非常に限定的な手法となってしまう。さらに， 現在市販されている抗コンドロイチン硫酸抗体や抗へパ ラン硫酸抗体などの糖鎖抗原に対する抗体が認識するエ ピトープは，バリエーションに富んだ硫酸化パターンの 中で糖鎖構造の微細な変化を検出することには不向きで ある、

そこで筆者らはより厳密に規定された特定硫酸化構造 を特異的に識別する分子プローブの収得を目指し，グリ コサミノグリカンの一種であるへパリンを標的として， ファージディスプレイ法を用いたペプチドプローブの創 出を試み，12残基のアミノ酸からなる HappY（Heparin- associated peptide $\underline{Y}$ ) ペプチドを報告した ${ }^{(4)}$.アンチ トロンビン結合性へパリンを標的として得られた HappYペプチドは，そのアミノ酸配列 [RTRGSTREF $\mathrm{RTG}$ ]の中の $1,3,7$ 番目のアルギニン残基が糖鎖構造内 の硫酸基と特異的に相互作用することにより，厳密に硫 酸化パターンを識別するプローブとして利用可能である ことが示されている。しかしながら，組織中の糖鎖構造 の変化を直接的に可視化するには，ペプチド_糖鎖間の 結合力の弱さを補い，プローブが構造特異的に結合した 糖鎖から解離しないようにする工夫が必要であった。

タンパク質同士の相互作用を解析する際，架橋試薬を 利用した化学的修飾法（クロスリンキング法）が利用さ れることがある.この方法は，生体内で起こる一時的な 分子間相互作用を解析できる点が特徴であり，これはま さにペプチドプローブがグリコサミノグリカンと相互作 用しているその瞬間を捉えることに応用可能であると筆 者らは考えた。現在，クロスリンキング法のための架橋 試薬が多数市販されているが，これらは光照射によりニ トレンやカルベンといった非常に反応性の高い化学的活 性種となり，近傍のアミノ酸や糖質と架橋を形成する. このような光アフィニティー標識部位と第 1 級アミンや $\mathrm{SH}$ 基と反応する部位，さらに検出時に利用するための ビオチンをそれぞれスペーサーで連結した分子（へテロ バイファンクショナルクロスリンカー）を用いて，筆者 らはHappYペプチドによるへパリンの検出を試みた ${ }^{(5)}$. まず，光架橋試薬「Mts-Atf-LC-Biotin（Thermo Fisher Scientific)」（図1）とC末端にシステイン残基を付加し たHappYペプチドを反応させ，システインの SH基に反 応性のあるメタンチオスルフォネート（Mts）基が HappYペプチドのシステイン残基と S-S 結合を形成す るようにし, HappY-Atf-LC-Biotin（HappYプローブ） を作製した。このプローブを用いて，組織内のへパリン と構造特異的な結合を形成させた後，引き続きこの状態 でUV（365nm）を照射すると，アジドテトラフルオロ （Atf）基が光反応によりニトレンを生じてプローブが結 合しているへパリンと架橋し，その結果HappYプロー ブとヘパリンが共有結合した状態になる，最後にビオチ ンを標的として検出することにより，ヘパリンの生体内 


\section{今日の話題}

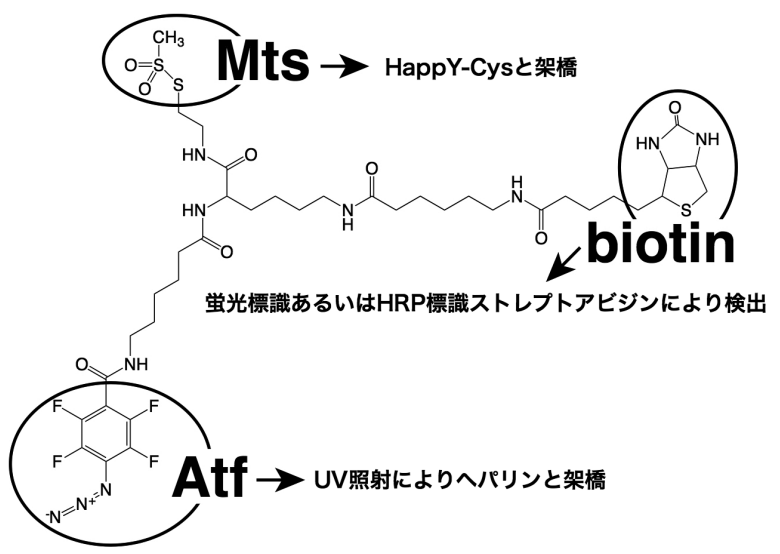

図 1 - 光架橋試薬「Mts-Atf-LC-Biotin (methanethiosulfonateazidotetrafluoro-long-chain-biotin)」の構造

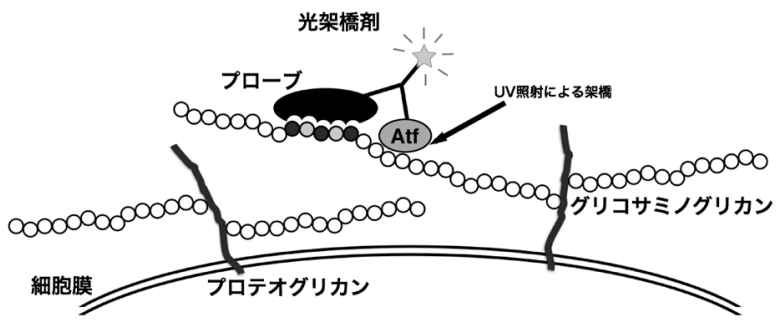

図 2 光架橋剤と構造特異的結合プローブを用いた細胞表面の グリコサミノグリカンの検出

局在を可視化することに成功した（図2）。これにより 筆者らは，ネコやイヌの皮膚の結合組織に存在する正常 肥満細胞が有するへパリンと，腫瘍化した肥満細胞が有 するへパリンの構造が異なることを発見し，臨床獣医師 の診断において良性と悪性の判断が非常に困難な肥満細 胞腫の簡易的診断の一助となることを示した ${ }^{(5)}$.

筆者らの開発した検出法が今後の生物学研究におおおい に貢献するためには，さらに多くのプロテオグリカン糖 鎖を構造特異的に認識するプローブが必要である。この
新規検出法の開発が硫酸化糖鎖構造特異的プローブの今 後のさらなる開発を触発し，組織内のグリコサミノグリ カン構造の時期・部位特異的変化を容易に可視化できる ようになることで，さまざまな生理機能をもたらすプロ テオグリカンの作用機序が解き明かされるようになるこ とを期待する.

1) R. V. Iozzo \& L. Schaefer: Matrix Biol., 42, 11 (2015).

2) N. Afratis, C. Gialeli, D. Nikitovic, T. Tsegenidis, E. Karousou, A. D. Theocharis, M. S. Pavão, G. N. Tzanakakis \& N. K. Karamanos: FEBS J., 279, 1177 (2012).

3) S. Sarrazin, W. C. Lamanna \& J. D. Esko: Cold Spring Harb. Perspect. Biol., 3, a004952 (2011).

4) T. Yabe, R. Hosoda-Yabe, Y. Kanamaru \& M. Kiso: J. Biol. Chem., 286, 12397 (2011).

5) T. Yabe, R. Hosoda-Yabe, H. Sakai, Y. Kanamaru \& M. Kiso: Anal. Biochem., 472, 1 (2015).

(矢部富雄，岐阜大学応用生物科学部)

プロフィール

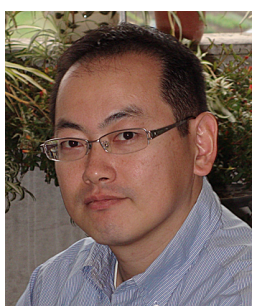

矢部 富雄 (Tomio YABE)

$<$ 略歴 $>1994$ 年東北大学農学部農芸化学科 卒業 / 1995年日本ロシュ(株)鎌倉研究所抗 真菌学部研修生 / 1996年東北大学大学院 農学研究科博士課程前期修了/同年日本学 術振興会特別研究員 $(D C 1) / 1999$ 年東北 大学大学院農学研究科博士課程後期修了 同年日本学術振興会特別研究員 $(\mathrm{PD}) /$ 同 年マサチューセッツ工科大学化学科博士研 究員/同年ハーバード大学医学部客員研究 員 / 2001年マサチューセッツ工科大学生物 学科博士研究員 $/ 2002$ 年東京都医学研究 機構東京都神経科学総合研究所常勤流動研 究員 / 2004 年岐皁大学応用生物科学部助 手 $/ 2007$ 年同准教授, 現在に至る<研究 テーマと抱負 >糖鎖構造制御による生物機 能の調節機構解明 <趣味 $>$ MLB と NFLの テレビ観戦, $\mathrm{FC}$ 岐阜の生観戦, 将棋

Copyright (C) 2016 公益社団法人日本農芸化学会 DOI: 10.1271/kagakutoseibutsu.54.231 